\title{
PENGARUH PERBEDAAN INDIVIDUAL TERHADAP HUBUNGAN ANTAR MANUSIA DALAM MANAJEMEN PSIKOLOGI
}

\author{
Oleh \\ Hafiz Al Ghifary (17002086) \\ UNIVERSITAS NEGERI PADANG \\ EMAIL: \\ alhafiz1221@gmail.com
}

\begin{abstract}
ABSTRAK
Hubungan antar manusia merupakan komunikasi antar pribadi yang manusiawi, berati komunikasi yang telah memasuki tahap psikologis yang komunikator dan komunikasinya saling memahami pikiran, perasaan dan melakukan tindakan bersama. Ini berarti bahwa apabila kita hendak menciptakan suatu komunikasi yang penuh dengan keakraban yang didahului oleh pertukaran informasi tentang adanya perbedaan individu ataupun masalah pribadi dari setiap individu yang bersifat sosial. Hubungan antar manusia mengandung arti suatu komunikasi yang sifatnya orientasi pada perilaku. Oleh karena itu, perusahaan atau organisasi seharusnya memahami dan menghargai perbedaan yang ada pada pegawainya, agar nantinya hubungan antar manusia yang baik dan harmonis bisa dilaksanakan dengan baik dan berjalan dengan lancer dan semestinya.
\end{abstract}

Kata Kunci : Hubungan antar manusia, komunikasi, perbedaan individu. 


\section{A. PENDAHULUAN}

\section{Latar Belakang Masalah}

Organisasi merupakan suatu wadah tempat berkumpulnya sejumlah orang yang menjalankan aktivitasnya sesuai dengan tanggung jawab yang diberikan. Dalam berorganisasi suatu perusahaan pastinya harus memiliki sumber daya manusia yang berbeda-beda. Salah satu strategi yang dapat ditempuh dalam membentuk sumber daya manusia agar mampu bekerja secara bersama-sama ialah dengan memberikan suatu kenyamanan pada karyawan agar mereka mampu bekerja secara baik, sehingga tidak terjadinya perbedaan antara karyawan yang satu dengan yang lainnya dan menciptakan suatu kelompok kerja yang solid serta membentuk sikap serta perilaku karyawan sesuai visi dan misi dari perusahaan atau organisasi tersebut.

Suatu perusahaan dalam melaksanakan kegiatannya juga harus memperhatikan perbedaan individual karyawannya, perbedaan individual tersebut harus kita perhatikan aspek-aspek yang memang harus diperhatikan, perbedaan individual tersebut terdapat aspek-aspek tingkat kecerdasan, bakat, keadaan jasmani, penyesuaian sosial dan emosional, latarbelakang keluarga, hasil belajar dan pendidikan, dan adanya gangguan pada jasmani dan penyesuaian sosial terhadap karyawan dari perusahaan atau organisasi tersbut.

Didalam hubungan antar manusia terdapat adanya perbedaan antar individu karyawan menyangkut perusahaan tersebut maka dilakukanlah peningkatan terhadap hasil kerja dari karyawan itu demi mencapai tujuan dari perusahaan agar dapat mempertahankan eksistensi dari perusahaan dalam dunia perbisnisan ataupun persaingan antar perusahaan .

\section{Rumusan Masalah}

Dari permasalahan yang ada maka dapat diungkapkan bahwa masih diperlukannya suatu kajian untuk mengkaji masalah pengaruh perbedaan individual terhadap hubungan antar manusia dalam manajemen psikologi karyawan pada suatu perusahaan. Dengan masalah tersebut kita harus mengetahui 
bagaimana pengaruh perbedaan individual terhadap hubungan antar manusia agar tidak terjadinya penyimpangan atau permasalahan yang dihadapi kedepannya nanti.

\section{Tujuan Penulisan}

Tujuan dari penulisan artikel ini ialah agar suatu perusahaan atau organisasi dapat melakukan kegiatannya dengan baik terutama bagi karyawannya dapat memberikan hasil yang diharapkan untuk menganalisis serta mengidentifikasi pengaruh perbedaan individual terhadap hubungan antar manusia karyawan dalam psikologi manajemen perusahaan.

\section{B. PEMBAHASAN}

\section{Ringkasan Artikel}

\subsection{Defenisi Hubungan Antar Manusia}

Organisasi merupakan tempat berkumpulnya orang-orang yang meiliki kepentingan yang sama dalam organisasi tersebut. Keberhasilan suatu organisasi dipengaruhi oleh kerja sama para personil dan semangat kerja yang mereka miliki dalam menjalankan tugasnya dalam organisasi.

Hal ini sangat ditekankan pada hubungan yang terjalin antar individu yang ada dalam organisasi tersebut hubungan antar individu merupakan salah satu faktor yang mempengaruhi kinerja pegawai dalam menjalankan tugas.

Dalam jurnal (Ermita, 2012) menurut Effendy (1993:48) mengemukakan ada dua pengertian hubungan antar manusia, yakni hubungan dalam arti luas dan arti sempit. Dalam arti luas, hubungan antar manusia adalah : komunikasi persuasive yang dilakukan seseorang kepada orang lain secara tatap muka dalam segala situasi kehidupan, sehingga menimbulkan kebahagiaan pada kedua belah pihak yang dilakukan dimana saja dan kapan saja serta dalam semua aspek 
kehidupan. Sedangkan hubungan antar manusia dalam arti sempit yaitu : komunikasi persuasif yang dilakukan seseorang kepada orang lain secara tatap muka dalam situasi kerja (work situation) dan dalam organisasi kekaryaan (work organization) dengan tujuan untuk menggugah kegairahan dan kegiatan untuk bekerja dengan semangat kerjasama yang produktif dengan perasaan bahagia dan puas hati.

Hubungan antar manusia di sisi lain diartikan sebagai keseluruhan rangkaian hubungan yang bersifat formal antara atasan dan bawahan, atasan dengan atasan, serta antara bawahan dengan bawahan yang harus dibina dan pelihara sedemikian rupa, sehingga terbentuknya suatu kerja sama dan suasana kerja yang intim dan harmonis dalam rangka mencapai tujuan organisasi.

Hubungan antar manusia menekankan pada hubungan sosial yang terjadi dalam organisasi dalam memahami hal ini, akan ada perbedaan pada tiap individu yang nantinya akan mempengaruhi hubungan sosial tersebut. Perbedaan tersebutlah yang harus dikoordinir oleh pimpinan agar perbedaan tersebut bukan hanya menjadi ancaman namun juga bisa menjadi sebuah peluang bagi organisasi.

Demikian pentingnya hubungan antar manusia bagi pegawai di suatu organisasi, dimana dengan adanya hubungan antar manusia yang baik akan tercipta saling pengertian dan kerja sama yang memperlancar organisasi dalam mencapai tujuan yang telah ditentukan sebelumnya. Dalam hal ini. Pemimpin perlu melakukan pembinaan HAM terhaadap pegawai di kantor agar tujuan dapat dicapai dengan sebaiknya. Pembinaan HAM dapai dilakukan dengan menetapkan sepuluh prinsip pokok hubungan antar manusia.

Menurut Siagian (1999:92), sepuluh prinsip tersebut adalah : a) Harus adanya singkronisasi antara tujuan dengan tujuan-tujuan individu, b) Suasana kerja yang menyenangkan, c) Informalitas yang wajar dalam hubungan kerja, d) Manusia bawahan bukan mesin, e) Kembangakan 
kemampuan bawahan sampai tingkat yang maksimal, f) Pekerjaan menarik penuh tantangan, g) Pengakuan dan penghargaan atas pelaksanaan tugas nyang telah dilakukan dengan baik, h) Alat perlengkapan yang cukup, i) Menempatkan orang pada tempat yang tepat,

j) Balas jasa harus seimbang dengan jasa yang diberikan (Ermita, 2012).

\subsection{Macam-Macam Hubungan Antar Manusia Dalam Organisasi}

a) Hubungan antara Pimpinan dengan Pegawai

Hubungan ini bersifat vertikal yang diperlukan dalam rangka menyampaian instruksi atau perintah, petunjuk arahan, bimbingan, dan pembinaan kepada pegawai dalam melaksanakan tugas.

Hubungan ini akan berimbas pada keinginan dan kemauan para pegawai dalam menerima perintah yang diberikan atasan. Tanpa adanya hubungan yang baik antara atasan dan bawahan, maka sulit terciptanya kerja sama yang baik dalam menjalankan tugas. Oleh sebab itu faktor komunikasi yang baik sangat diperlukan dalam rangka mencipatakan hubungan yang harmonis bagi kedua belah pihak dalam melaksanakan tugas dan fungsi masing-masing di organisasi.

b) Hubungan antar Pegawai dengan Pegawai

Hubungan ini bersifat horizontal yang diperlukan unutk menciptakan koordinasi, persamaan perspsi, berdiskuis dan bertukar pendapat, saling membantu antar sesama pegawai dalam pelaksanaan tugas di organisai.

Hubungan anatar pegawai merupakan hubungan kerja sama yang diperlukan bagi organisasi dan akan berdampak pada kinerja organisasi. Komunikasi yang baik dalam hal ini sangat diperlukan untuk mmenjalin kerja sama tim anatr pegawai agar mereka nantinya bisa saling membantu dalam menyelseasikan tugas dan berbagi pendapat (Mangkunegara, 1993). 
Dengan demikian dapat disimpulkan bahwa hubungan antar manusia perlu diciptakan di organisasi, karena dengan adanya hubungan antar manusia akan timbul hubngan kekeluaragaan dan keakraban, kerja sama yang baik. Komunikasi yang harmonis antara pimpinan dan bawahan, antara sesama pegawai serta antara pegawai dengan yang lainnya.

\subsection{Perbedaan Individual}

(Tobing, 2013) mengatakan bahwa setiap individu memiliki perbedaan dengan individu yang lainnya, hal ini merupakan yang wajar dan perbedaan ini pasti ada dalam sebuah organisasi. Perbedaan ini bukan hanya meliputi hal seperti ras, etnis, gender, namun lebih luas lagi mencakup variabel usia, pendidikan, bahasa, agama, dan lain-lain. Dimensi-dimensi tersebut merupakan karakteristik penting pada diri seseorang yang berpengaruh pada nilai-nilai, kesempatan, dan persepsi individu terhadap dirinya dan orang lain.

Karakteristik tersebut merupakan hal yang berbeda antara satu orang dengan orang lainnya, yang selanjutnya akan mempengaruhi cara kerja mereka dan akhirnya akan mempengaruhi perusahaan atau organisasi seecara keseluuruhan.

\subsection{Macam-Macam Perbedaan Individu}

Adapun macam-macam atau jenis dan ciri perbedaan individual menurut (Hamalik, 1993) adalah sebagai berikut:

a) Kecerdasan

Setiap pegawai akan memiliki kecerdasan yang berbeda antara satu dengan yang lainnya, ada pegawai yang memiliki tingkat kecerdasan yang tinggi yang biasanya mempunayi tingkat perhatian yang lebih baik, bekerja cepat, mudah memahami pekerjaan, dan dapat menyelesaikan pekeerjaan dalam waktu yang singkat serta mampu mencari solusi jika ada masalah dalam pekerjaannya. 
b) Bakat

Tiap pegawai akan memiliki bakat yang berbeda, dan biasanya bakat akan turut mempengaruhi tingakt keberhasilan kerja. Untuk mengetahui bakat individu dapat diadakam tes pada saat penerimaan pegawai baru untuk menentukan tugas pegawai tersebut sesuai dengan bakat yang dimilikinya.

c) Keadaan Jasmani

Hal ini berkaitan dengan kondisi jasmani para pegawai, ada pegawai yang memiliki badan tinggi maupun kurus, pegawai yang kurus dan gemuk, serta adanya pegawai yang memiliki kondisi badan yang buruk, kesulitan berkomunikasi, dan penyakit dalam dirinya.

d) Latar Belakang Keluarga

Individu berasal dari keluarga yang berbeda antar satu dengan yang lainnya, dalam hal latar belakang keluarga tiap individu akan mengadopsi budaya dalam keluarganya yang nantinya hal inilah yang akan menimbulkan perbedaan antar satu indiviu dengan individu lainnya.

e) Sosial Emosioanl

Individu akan memiliki perbedaan dalam hal sosial emosional, hal ini disebabkan karena latar belakang sosial individu tersebut dan pengaruh emosional dalam diri individu yang membedakan satu individu dengan individu dengan indiviu lainnya.

\subsection{Pengaruh Perbedaan Individu Terhadap Hubungan Antar Manusia Dalam Organisasi}

Setiap individu memiliki perbedaan antara satu dengan yang lainnya, ada yang memiliki kecerdasan intelektual yang tinggi dan ada yang tidak, ada yang memiliki tubuh tinggi dan ada yang rendah. Semua hal tadi perlu diperhatikan dalam sebuah organisasi, karena dengan memahami perbedaan yang ada pada individu akan memudahkan seseorang untuk 
memahami orang lain, dan hasil akhirnya akan terciptanya hubungan kerja sama dan saling pengertian antar satu individu dengan individu lainnya.

Hubungan yang baik antar manusia dalam organisasi bisa tercipta karena adanya pemahaman yang baik terhadap perbedaan yang terjadi dalam organisasi, contohnya seorang manajer yang memahami perbedaan bakat pada tiap personilnya tentu akan memudahakannya dalam menentukan dan memberikan perintah kepada personil tersebut sesuai dengan bakat yang dimiliki, hal lainnya seperti seorang manajer akan memberikan bimbingan kepada personil yang memiliki kecerdasan dan kemampuan yang kurang dalam melaksanakan pekerjaannya.

Dari hal diatas dapat disimpulkan bahwa hubungan antar individu akan semakin baik jika mereka masing-masing memahami dan menghargai perbedaan yang ada dalam diri seseorang, semakin baik seseorang dalam memahami perbedaan individu maka akan berdampak pada hubungan orang tersebut dengan orang lain dalam sebuah organisasi.

\section{Kajian Analitis}

1) Deresky (2000)

Perbedaan Individual merupakan pembedaan karakteristik antara satu individu dengan individu lain, yang nantinya hal ini akan mempengaruhi kinerja mereka dalam menjalankan tugas dan juga akan mempengaruhi perusahaan secara keseluruhan.

2) Effendy (1993:84)

Hubungan antar manusia diartikan sebagai pemberian makna terhadap proses rohaniah yang tertuju pada kebahagiaan dan kepuasan 
yang berdasarkan kepada watak, sifat, perangai, kepribadian, tingkah laku, dan aspek kejiwaan lainnya yang terdapat pada diri manusia.

Didalam perbedaan yang ada individu akan berpengaruh pada hubungan antar manusia dimana hubungan manusia yang tertuju pada kebahagiaan akan memerlukan proses dimana seorang individu perlu memahami dan mengahargai perbedaan watak, sifat, kepribadian, dan tingkah laku yang ada pada diri orang lain. Jika seseorang sudah bisa memahami perbedaan tersebut maka hubungan antar manusia dalam sebuah organisasi tentu akan mudah untuk dilaksanakan karena suatu hubungan bisa berjalan dengan baik jika masing-masing perbedaan telah berhasil dipahami dan dihargai oleh orang yang bersangkutan.

\section{PENUTUP}

\section{Kesimpulan}

Hubungan antar manusia dalam organisasi adalah hubungan sosial yang terjadi antara anggota sebuah organisasi. Dalam hal ini terdapat perbedaan ondiviudal yang harus bisa dipahami masing-masing individu agar seorang individu bisa menjalin hubungan dan kerja sama dengan indiviu lainnya.

Perbedaan individual ini jika tidak dipahami dengan benar maka akan mempersulit individu untuk berhubungan dengan individu lainnya, karena dengan pemahaman terkait perbedaan individual akan berpengaruh terhadap hubungan antar manusia dalam sebuah organisasi.

\section{Saran}

Sebaiknya konsep terkait perbedaan individual perlu dipahami dengan baik dan juga terkait hubungan antar manusia dalam sebuah organsiasi perlu diperhatikan, karena hal ini berdampak pada keberlangsungan jalan atau tidaknya suatu organisasi dan baik atau buruknya kinerja pegawai dalam sebuah organisasi. 


\section{REFERENSI}

Ermita. (2012). Hubungan Antar Manusia dan Semangat Kerja Pegawai. PEDAGOGI, Jurnal Ilmiah Ilmu Pendidikan, XII(2), 70-81.

Hamalik, O. (1993). Psikologi Manajemen Penuntun Bagi Pemimpin. Bandung: Trigenda Karya.

Mangkunegara, A. (1993). Psikologi Perusahaan. Bandung: Trigenda Karya.

Tobing, D. S. K. (2013). Pengaruh Perbedaan Individual Dan Budaya Organisasi Terhadap Manajemen Perubahan PTPN XII Kebun Kendeng Lembu Glenmore Di Banyuwangi. Journal of Chemical Information and Modeling, 53(9), 1-11. 